\title{
Pattern of Motion Restriction in Nigerian Patients with Knee Osteoarthritis
}

\author{
Akinpelu, A.O. ${ }^{1}$, lyor, F.T. ${ }^{2}$, Odole, A.C. ${ }^{1}$ \\ ${ }^{1}$ Physiotherapy Department, College of Medicine, University of Ibadan, Ibadan, Nigeria \\ ${ }^{2}$ NKST Rehabilitation Hospital, Mkar, PMB I93, Gboko, Benue State, Nigeria \\ Correspondence \\ Dr. O.A. Akinpelu, Physiotherapy Department, College of Medicine, University of Ibadan, Ibadan, Nigeria \\ •Email: aderonkeakinpelu@yahoo.com
}

\begin{abstract}
SUMMARY
In the $\mathrm{W}$ estern population, knee osteoarthritis $(\mathrm{OA})$ has been shown to present a characteristic passive motion restriction pattern, called the capsular pattern (extension restriction to flexion restriction ratio ranging from 0.03 to 0.50 ). The pattern of motion restriction of Nigerian patients with $\mathrm{OA}$ has not been previously reported. This study was conducted to determine the pattern of motion restriction in Nigerian patients with knee osteoarthritis.

Participants were 50 patients with knee OA (OA Group/OAG), recruited consecutively from two secondary health institutions and 50 age and sex-matched controls (Control Group/CG) without symptoms of OA. Goniometric measurements of passive and active knee motion of participants were taken. Data was analysed using the independent t-test.

The $\mathrm{OAG}$, aged $58.1 \pm 10.7$ years has had $\mathrm{OA}$ for $4.0 \pm 4.5$ years. The CG was aged $55.9 \pm 10.3$ years. Mean active extension $\left(1.5 \pm 5.2^{\circ}\right)$ of the $\mathrm{OAG}$ differed significantly $(\mathrm{P}<0.05)$ from that of the $\mathrm{CG}\left(0^{\circ}\right)$, but the two groups did not differ significantly in passive extension $\left(\mathrm{OAG}=1.2^{\circ} \pm 4.4^{\circ} ; \mathrm{CG}=0^{\circ}\right)$. The $\mathrm{CG}\left(125.9^{\circ} \pm 4.6^{\circ}\right) \mathrm{had}^{\circ}$ significantly higher $(\mathrm{P}=0.0001)$ active knee flexion than the $\mathrm{OAG}\left(99.9^{\circ} \pm 15.5^{\circ}\right)$. $\mathrm{Passive}$ knee flexion of the CG $\left(134.5^{\circ} \pm 5.0^{\circ}\right)$ was significantly higher $(\mathrm{P}=0.000)$ than that of the OAG $\left(110.4^{\circ} \pm 14.8^{\circ}\right)$. Mean active extension and flexion restriction of $\mathrm{OAG}$ was $2.1 \pm 5.7^{\circ}$ and $26.0 \pm 15.4^{\circ}$ respectively. Mean passive extension restriction was $1.2 \pm 4.4^{\circ}$ and passive flexion restriction was $24.0 \pm 14.8^{\circ}$, giving a ratio of 0.05 for $\mathrm{OAG}$.

Our findings suggest that the passive motion restriction pattern seen in Nigerian patients with knee osteoarthritis is the capsular pattern.
\end{abstract}

KEY WORDS: motion restriction, patients, knee osteoarthritis

\section{INTRODUCTION}

Osteoarthritis (OA) is the most common joint disease in the elderly and a leading cause of disability in the world (Yeomans, 2000). It affects $60-70 \%$ of the population older than 60 years (Lane, 1997). The most frequently affected joint in Nigerian patients is the knee (Ogunlade et al., 2003; Akinpelu et al., 2007). The prevalence estimate of symptomatic knee $\mathrm{OA}$ in Nigerian rural community dwellers aged $\geq 40$ years is $19.6 \%$ (Akinpelu et al., 2009).

One of the features of osteoarthritis is motion restriction (Ward and Tidswell, 1985). Cyriax (1978) observed the patterns of passive motion restriction in various joints of the body. He proposed the theory that, at every joint affected by inflammatory or degenerative disease, the proportion that the limitation or restriction of motion in one direction bears to that in other directions conforms to a standard which indicates whether arthritis is present or not. This proportional limitation Cyriax (1978) called a 'capsular pattern'. For the knee, he defined the capsular pattern as a gross limitation in flexion (e.g. $90^{\circ}$ ) and a slight limitation in extension (e.g. $5^{\circ}-10^{\circ}$ ). According to Cyriax (1978), non-capsular patterns of motion restriction are associated with ligamentous adhesions, internal derangement and extra-articular lesions. Orthopaedic Medicine Teachers in the United Kingdom also defined capsular pattern for the knee as much greater loss of flexion range than extension without recourse to figures (Ellis, 1995). The concept of capsular pattern has been used over time by clinicians to evaluate joints. However, Cyriax (1978) did not supply any evidence to support this concept (Fritz et al., 1998). This probably prompted a few studies, conducted with the view to seek evidence in support of the capsular pattern concept, but results have been conflicting. Hayes et al. (1994) evaluated 
the capsular pattern in patients with knee OA and concluded that the validity of capsular pattern for identifying patients knee OA was questionable. These authors suggested that a proportional definition of a capsular pattern should be abandoned, but the concept of a pattern of range of motion loss may be useful. On the other hand, Fritz and colleagues (1998) in addition to demonstrating the capsular pattern in osteoarthritis of the knee also provided a proportional and objective definition based on the ratio of the loss of passive extension to loss of passive flexion. These authors concluded that a proportion of passive extension loss or restriction to passive flexion restriction between 0.03 and 0.50 best differentiated between individuals with and without arthritis.

The pattern of motion restrictions has not been studied in Nigerian patients. The aim of this study was therefore to determine the pattern of motion restrictions in Nigerian patients with knee OA.

\section{MATERIALS AND METHODS}

The Ethical Committee of the Federal Medical Centre, Makurdi, Nigeria approved the study. Fifty patients diagnosed with unilateral or bilateral knee osteoarthritis (OA group) by the referring surgeons/physicians and 50 age and sex-matched controls without pain or other symptoms of knee osteoarthritis (control group) participated in the study. Patients with knee OA were recruited consecutively from physiotherapy and surgical outpatient clinics of the NKST Rehabilitation Hospital, Mkar and the Federal Medical Centre, Makurdi, both in Benue State, Nigeria. Diagnosis of OA was based on clinical signs and radiological findings. The controls were members of staff of the two hospitals and relations of patients. Participants did not have any other musculoskeletal or neurological problem, such as chronic low back pain, hip OA and hemiparesis.

The procedure was explained to participants and each gave his/her consent. Participants were interviewed to obtain their biodata and clinical history was obtained through interviews and from their hospital files. Weight and height were measured. Passive range of motion was measured on the affected knee or the more affected knee in patients with bilateral knee osteoarthritis, using a pliable universal goniometer $\left(\right.$ Olfe $\left.{ }^{\mathrm{TM}}\right)$. Goniometric measurement of knee motions was taken according to the American Academy of Orthopaedic Surgeons' (AAOS) protocol (AAOS, 1965). Knee flexion was measured with participants in prone position, while extension was measured with the subject lying prone, but with the legs extended over the end of the plinth, such that the patellae was free in space over the end of the plinth and lower parts of the femurs supported (Edwardson, 1992). The goniometer was placed on the lateral aspect of the knee with the fulcrum over the lateral epicondyle. The stationary arm of the goniometer was aligned with the mid-line of the femur towards the greater trochanter and the movable arm aligned with the mid-line of the fibula towards the lateral malleolus. The axis of the goniometer and the two ends of the arms were marked on the knee, thigh and leg respectively, with a marker to ensure accuracy. Each participant was asked to perform the test motion actively or the motion was passively performed by the tester. Three measurements were taken for each motion and the average of the three readings was recorded as the value for the movement. Active motions were measured before passive motion (AAOS, 1965). In order to calculate values of passive knee extension and flexion restriction of participants in the OA group, the mean passive extension and flexion of the control group was taken as normal values and each participant's passive extension/flexion was subtracted from the corresponding mean value.

Data was summarized using descriptive statistics (mean, standard deviation and ratio). Independent student t-test was used to compare the active and passive knee motion and motion restrictions of the two groups. P value was set at 0.05 .

\section{RESULTS}

The age of the OA group (23 males, 27 females) ranged from 40 to 80 years and the mean was $58.1 \pm 0.7$ years. For the control group ( 23 males, 27 females), it ranged from 40 to 73 years, with a mean of $55.9 \pm 10.3$ years. The duration of osteoarthritis averaged $4.0 \pm 4.5$ years. Most of the participants were civil servants and farmers (table 1 ). In the OA group, 27 participants (10 males, 17 females) had bilateral knee involvement, 14 ( 7 males, 7 females) were affected on the left and 9 ( 6 males and 3 females) had right knee affected. Left and right knees were assessed in 26 and 24 participants respectively. The two groups did not differ significantly in age (table 1 ).

Mean active extension was $1.5^{\circ} \pm 5.2^{\circ}$ for the OA group while it was $0^{\circ}$ for the control group. Mean passive extension was $1.2^{\circ} \pm 4.4^{\circ}$ for the $\mathrm{OA}$ group and $0^{\circ}$ for the control group. For the OA group, mean active flexion was $99.9^{\circ} \pm 15.5^{\circ}$ and for the control group, it was $125.9^{\circ} \pm 4.6^{\circ}$. Mean passive flexion was $110.4^{\circ} \pm 14.8^{\circ}$ for the OA group 
and $134.5^{\circ} \pm 5.0$ for the control group. Mean active extension for the $\mathrm{OA}$ group differed significantly from that of the control group $(\mathrm{P}=0.05)$ but there was no significant difference between the passive extension of both groups. The control group exhibited a significantly greater active knee flexion $(\mathrm{P}=0.000)$ and passive knee flexion $(\mathrm{P}=$ $0.000)$ than the OA group.

Table 1. Sociodemographic characteristics of participants

\begin{tabular}{lcc}
\hline & OAG & CG \\
\hline Age (years) & 58.1 & 55.9 \\
Mean & 10.7 & 10.3 \\
Standard deviation & & \\
Sex & 23 & 23 \\
$\quad$ Male & 27 & 27 \\
Female & & \\
Height (cm) & 163.3 & 163.4 \\
Mean & 6.3 & 6.7 \\
Standard deviation & & \\
Weight (kg) & 76.0 & 74.4 \\
Mean & 12.0 & 8.4 \\
Standard deviation & & \\
Occupation & 18 & 30 \\
Farmers & 7 & - \\
Traders & 18 & \\
Civil servants & 7 & \\
Others & & \\
\hline
\end{tabular}

OAG - OA group

OA - osteoarthritis

Table 2. Active and passive knee motions of participants

\begin{tabular}{|c|c|c|c|c|c|c|}
\hline & \multicolumn{2}{|c|}{ OA Group } & \multicolumn{2}{|c|}{ Control Group } & \multirow[b]{2}{*}{ t-value } & \multirow[b]{2}{*}{$\mathrm{p}$} \\
\hline & Mean & $\mathrm{SD}$ & Mean & SD & & \\
\hline $\begin{array}{l}\text { Active knee } \\
\text { extension }\left({ }^{\circ}\right)\end{array}$ & 1.5 & 5.2 & 0.0 & 5.2 & 1.987 & $0.050^{*}$ \\
\hline $\begin{array}{l}\text { Passive knee } \\
\text { extension }\left({ }^{\circ}\right)\end{array}$ & 1.2 & 4.4 & 0.0 & 0.0 & 1.876 & 0.064 \\
\hline $\begin{array}{l}\text { Active knee } \\
\text { flexion }\left({ }^{\circ}\right)\end{array}$ & 99.9 & 15.5 & 125.9 & 4.6 & -11.369 & $0.000^{*}$ \\
\hline $\begin{array}{l}\text { Passive knee } \\
\text { flexion }\left({ }^{\circ}\right)\end{array}$ & 110.4 & 14.8 & 134.5 & 5.0 & -10.861 & $0.000^{*}$ \\
\hline${ }^{*}=$ significan & rence & & $\left({ }^{\circ}\right)-\mathrm{d}$ & & & \\
\hline OA - osteoart & & & $\mathrm{SD}-\mathrm{s}$ & $\operatorname{ard~d}$ & eviation & \\
\hline
\end{tabular}

For the OA group, the mean restriction of active knee extension and flexion was $2.1^{\circ} \pm 5.7^{\circ}$ and $26.0^{\circ} \pm 15.4^{\circ}$ respectively. Majority (92\%) of the participants in the OA group did not exhibit any restriction of passive knee extension. The passive knee extension restriction demonstrated by the remaining four participants in the $\mathrm{OA}$ group ranged from $5^{\circ}$ to $23^{\circ}$. The mean restriction of passive knee extension for the group was $1.2^{\circ} \pm 4.4^{\circ}$. All participants in the OA group demonstrated restriction of passive knee flexion $\left(4.5^{\circ}\right.$ to $\left.59.5^{\circ}\right)$ and the mean value was $24.0^{\circ} \pm 14.8^{\circ}$. The ratio of passive knee extension to flexion restriction was $(1.2: 24) 0.05$.

Table 3. Passive knee motion restrictions of OA group

\begin{tabular}{lccc}
\hline & Range & Mean & SD \\
\hline $\begin{array}{l}\text { Passive knee } \\
\text { extension restriction }\end{array}$ & $5-23$ & 1.2 & 4.4 \\
$\begin{array}{l}\text { Passive knee flexion } \\
\text { restriction }\end{array}$ & $4.5-59.5$ & 24.0 & 14.8 \\
\hline
\end{tabular}

$\left({ }^{\circ}\right)$ - degrees $\quad$ SD - standard deviation

\section{DISCUSSION}

The mean age $(58.1 \pm 10.7$ years $)$ of the OA group in this study is within the range reported by previous studies (Hannan et al., 1993; Lohmander et al., 1993; Zhang et al., 1995). Their gender distribution (27 females and 23 males) also supports the female bias reported by previous studies on pattern of OA in Nigeria (Ogunlade et al., 2005; Akinpelu et al., 2007).

The mean passive flexion $\left(134.5 \pm 5.0^{\circ}\right)$ of the control group is very close to the normal value $\left(135^{\circ}\right)$ published by the American Academy of Orthopaedic Surgeons (AAOS, 1965). The finding that almost all participants in the OA group recorded full passive knee extension $\left(0.0^{\circ}\right)$ is inconsistent with the findings of previous studies that reported inability of most participants to attain full passive knee extension (Walker, 1984; Mollinger and Steffan, 1993). The reason for this difference could be that relatively younger individuals with $\mathrm{OA}$ were involved in the present study.

The finding that the OA group demonstrated significantly lower active knee extension and flexion and passive knee flexion supports the fact that limitations of range of motion are a feature of osteoarthritis. The results of this study also indicate that patients with knee OA tend to exhibit more limitation of knee flexion than limitation of extension. The proportional passive knee extension restriction to passive knee flexion restriction of the $\mathrm{OA}$ group supports the idea of capsular pattern. Although the 
mean passive motion restrictions $\left(1.2^{\circ} \pm 4.4^{\circ}\right.$ of extension and $24.0^{\circ} \pm 14.8$ of flexion restriction) are a lot less than the $5^{\circ}$ for extension and $90^{\circ}$ for flexion described by Cyriax (1978), the ratio of passive knee extension restriction to passive knee flexion restriction of the OA group (0.05) is within the range (0.03-0.5) recommended by Fritz et al. (1998) for defining capsular pattern. This proportional motion restriction differentiates the OA group from the control group, who demonstrated no restriction. The capsular pattern may therefore be used along with other clinical criteria for knee OA diagnosis, such as the criteria of the American College of Rheumatology where radiographic facilities are not readily available.

\section{CONCLUSION}

Our findings suggest that the pattern of passive motion restriction in knee osteoarthritis seen in Nigerian patients is similar to the capsular pattern described for the Western population.

\section{References}

Akinpelu, O.A., Odole, A.C., Adegoke, B.O.A. and Adeniyi, A.F. (2007) Development and initial validation of Ibadan Knee/Hip Osteoarthritis Outcome Measure. South African Journal of Physiotherapy 63, 3-7.

American Academy of Orthopaedic Surgeons' Committee for the Study of Joint Motion (AAOS) (1965) Joint Motion: Method of measuring and recording. Chicago: The American Academy of Orthopaedic Surgeons.

Cyriax, J. (1978) Textbook of Orthopaedic Medicine, Vol 1: Diagnosis of soft Tissue lesions. $7^{\text {th }}$ edition, London, England: Bailliere Tindall.

Edwardson, B.M. (1992) Musculoskeletal Assessment: an integrated approach. Singular publishing group inc. California.

Ellis R.M. (1995) A letter to colleagues. The American Academy of Orthopaedic Medicine Quarterly Newsletter 11: 4 - 5.
Fritz, J.M, Delitto, A, Erhard, R.E and Roman, M. (1998) An examination of the selective tissue tension scheme, with evidence for the Concept of a Capsular pattern of the knee. Physical Therapy 78: 1046 - 1056.

Hannan, M.T., Anderson, J.J., Zhang, Y., Levy, D., and Felson, D.T. (1993) Bone mineral density and knee osteoarthritis in elderly men and women: the Framingham study. Arthritis and Rheumatism 36: $1671-1680$.

Lane, N.E. (1997) Pain management in osteoarthritis. The role of cox-2 inhibitors. Journal of Rhematology 24: 20-24 (suppl).

Lohmander, L.S, Hoerrner, L.A, and Lark, M.W. (1993) Metalloproteinases, tissue inhibitor, and proteoglycan fragments in knee synovial fluid in human osteoarthritis. Arthritis and Rheumatism 36: 181 - 189.

Mollinger, L.A. and Steffan, T.M. (1993) Knee flexion contractures in institutionalised elderly: Prevalence, severity, stability and related variables. Physical Therapy 73: 437-441.

Norkin, C.C and White D.J (1995) Measurement of Joint Motion: $A$ guide to goniometry. $2^{\text {nd }}$ edition, FA Company. Philadelphia.

Oyemade, G.A. (1981) A double blind comparison of proquazone (biarson with indomathacin in patients with musculoskeletal disorders. Current Therapeutic Research 29: 5 - 10.

Roach, K.E. and Miles, T.P. (1991) Normal hip and knee active ranges of motion: The relationship to age. Physical Therapy 71: 655 - 659.

Walker, J.M (1984) Active mobility of the extremities in older subjects. Physical Therapy 64: 919 - 922.

Ward, D.J. and Tidswell, M.E. (1985) Osteoarthritis. In: Downie, P.A. (ed) Cash's textbook of orthopadics and rheumatology for physiotherapists. Faber and Faber Ltd. London. Pp: 385 - 410.

Zhang, N., Shi, Q. and Zhang, X. (1995) An epidemiological study of knee osteoarthritis. Chinese Journal of Internal Medicine 34:84-88. 